\title{
FISH DIVERSITY AND ITS THREATENED STATUS OF THE DHARLA RIVER IN BANGLA- DESH
}

\author{
Md. Ashraful Alam ${ }^{1}$, Yeasmin Ara², Imran Parvez ${ }^{2}$, Jayanto Kumar Roy ${ }^{1}$, Macksood Alam Khan ${ }^{1}$ \\ ${ }^{1}$ Faculty, Rural Development Academy (RDA), Bogura, Bangladesh \\ ${ }^{2}$ Faculty of Fisheries, Hajee Mohammad Danesh Science and Technology University (HSTU), Dinajpur, Ban- \\ gladesh
}

*Corresponding Author: ashhstu019@gmail.com

\section{ARTICLE INFO}

Received: 15 April 2020

Accepted: 17 January 2021

\section{Keywords:}

Indigenous fish

IUCN

Biodiversity indices

Conservation

\section{ABSTRACT}

Fish diversity of a riverine ecosystem became reduced due to different manmade and natural calamities. This study investigated the present fish biodiversity status of the Dharla River located $\left(25.8103^{\circ} \mathrm{N}, 89.6487^{\circ} \mathrm{E}\right)$ in the northern part of Bangladesh from January to December 2018. In this study, the existing fish biodiversity status of the Dharla River was estimated in terms of diversity indices and threatened status (both global and local). Data was collected from the three sampling sites of the river using different fishing gears and three selected fish markets located in the Kurigram district of Bangladesh. A total of 76 fish species were identified belonging to 8 orders, 26 families and 57 genera. The Cyprinidae was the most dominant family represented by 14 species followed by the Danionidae (13 species), Bagridae (8 species) and few minor families. Apart from the indigenous species, nine exotic fish species were also recorded. The Shannon-Weaver diversity $(H)$, Pielous evenness $(e)$ and Margalef richness $(D)$ indices ranged from 3.00 to $3.71,0.62$ to 0.94 and 3.94 to 7.95 , respectively. Out of 76 indigenous species, 28 species (37\%) were identified as threatened in Bangladesh, which included critically endangered (4), vulnerable (9) and endangered (15) species. Indiscriminate fishing through poisoning and destructive fishing gears were identified as the major threats to fish biodiversity of the Dharla River. Thus, the river serves as considerable support for threatened indigenous fishes. Therefore, necessary steps are needed to stop destructive fishing, establish permanent fish sanctuaries and proper monitoring for maintaining sustainable biodiversity in the Dharla River.

Alam, M. A., Ara, Y., Parvez, I., Roy, J. K., Khan, M. A. (2021): Fish diversity and its threatened status of the Dharla River in Bangladesh. Croatian Journal of Fisheries, 79, 163-172. DOI: 10.2478/cjf-2021-0018. 


\section{INTRODUCTION}

The freshwater ecosystem is the world's richest ecosystem containing about $41.24 \%$ of known fish species (Gökçe, 2019). Bangladesh is enriched with $24,140 \mathrm{~km}$ of rivers, 114,161 ha of natural depressions or beels, 5,488 ha of oxbow lakes, 68,800 ha of reservoirs and some 2.7 million ha of floodplains in terms of inland water resources (DoF, 2019). Also, Bangladesh is considered a riverine country, including 310 rivers with their tributaries (BBS, 2018) flowing throughout the country.

The diverse vast inland water bodies supported 265 indigenous freshwater fish species of Bangladesh (Rahman, 2005). Furthermore, Bangladesh is positioned fifth in the production of freshwater fishes and rivers serve as brood banks for this purpose (DoF, 2019). However, rapid population increase in Bangladesh declined the freshwater fish very hastily from the river ecosystem (Galib et al., 2009). Overexploitation of natural fishes occurred to meet the food protein demand of the people. Unplanned management of the river water for agriculture and industrial activities led to the extinction of freshwater fish species from the rivers (IUCN 2015). Unplanned construction of roads, sluice gates, dams and bridges blocked many migratory routes and caused the devastation of fish habitat, nursery and breeding grounds (IUCN 2015). Conversion of inundated land to cropland (Chakraborty and Nur, 2009), invasion of exotic species, aquatic pollution, unplanned exploitation, discharges from industries and municipal sewerage, and global climate change led to the threat of many indigenous species (Rao et al., 2014; Siddik et al., 2014; Sharker et al., 2015). IUCN (2015) declared 64 fish species in Bangladesh as threatened among 253 assessed species, whereas the number of threatened species was 54 in 2000.

The Dharla River is one of the transboundary rivers flowing in northern Bangladesh. It originates from Kupup or Bitang Lake in southeastern Sikkim in the eastern Himalayas, known as the Jaldhaka River, and flows through Bhutan and the Kalimpong, Jalpaiguri and Cooch Behar districts of West Bengal, India. The Dharla River enters into Bangladesh through the Lalmonirhat district and joins together with the Jaldhaka River then flows with the Dharla River until it empties into the Brahmaputra River near the Kurigram district (Chowdhury, 2012).

A scientific understanding of management is very important in order to conserve fish biodiversity and ensure sustainability in natural water bodies (Hanif et al., 2015). For sustainable management of a riverine ecosystem, diversity indices reveal more information on scarcity and commonness in their community, rather than the simple relationship of the species present in specific water bodies (Hanif et al., 2015). Although several studies have been conducted on assessing fish biodiversity of different rivers in Bangladesh (Imteazzaman and Galib, 2013; Hanif et al., 2015; Galib, 2015; Siddique et al., 2016;
Parvez et al., 2017; Parvez et al., 2019), studies on the fish diversity of the Dharla River remained untouched till now. Therefore, the present study aimed to conduct an assessment of indices based on fish biodiversity of the Dharla River with their threatened status.

\section{MATERIALS AND METHODS}

\section{Study area and duration}

The study was conducted on the Dharla River at the Kurigram district $\left(25.8103^{\circ} \mathrm{N}, 89.6487^{\circ} \mathrm{E}\right)$ in the northern part of Bangladesh (Figure 1) from January to December 2018. The fish samples were collected twice a month from three selected sites (S-1: $25^{\circ} 51^{\prime} 50.7^{\prime \prime} \mathrm{N} 89^{\circ} 36^{\prime} 39.0^{\prime \prime} \mathrm{E}$, S-2: $\quad 25^{\circ} 47^{\prime} 37.0^{\prime \prime} \mathrm{N} \quad 89^{\circ} 39^{\prime} 03.6^{\prime \prime} \mathrm{E}, \quad \mathrm{S}-3: \quad 25^{\circ} 51^{\prime} 32.4^{\prime \prime} \mathrm{N}$ $\left.89^{\circ} 36^{\prime} 01.3^{\prime \prime} \mathrm{E}\right)$ at early morning and three markets (Buraburi Bazar-25⒋'36.2" $\mathrm{N} 89^{\circ} 40^{\prime} 59.9^{\prime \prime} \mathrm{E}$, Mogalbasa

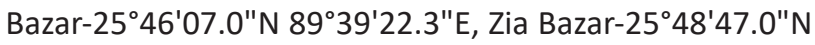
$\left.89^{\circ} 38^{\prime} 58.7^{\prime \prime} \mathrm{E}\right)$ at noon in the study area. The fishermen used gill nets (mesh size 0.5-1.27 cm), cast nets (mesh size 0.4-1.1 cm), lift nets/dip nets (mesh size 0.3-1.2 cm) and different types of traditional fishing traps like conical traps, fish barrier (Thaga) to catch the fish. Fishes were collected and counted on the spot, and then categorized. The identified and unidentified fishes were preserved into the $10 \%$ formalin at the fish laboratory in Hajee Mohammad Danesh Science and Technology University (HSTU), Dinajpur for further study.

\section{Identification and conservation status of fishes}

The collected fish from the selected study areas were identified based on their morphometric characters and meristic counts following Talwar and Jhingran (1991), Rahman (2005). Updated taxonomic framework followed Eschmeyer (2014). It is very important to know the conservation status of fish biodiversity for taking future strategies to maintain the sustainability of the riverine ecosystem. To serve this purpose, the conservation status and risk of extinction were determined according to IUCN (2015).

\section{Data analyses}

Species diversity indices, i.e. Shannon-Weaver diversity index $(H)$, Margalef's richness index $(D)$, Pielou's evenness (e), of the Dharla River were calculated by using PAST version 4.02 through the following way:

Shannon-Weaver diversity index, $\mathrm{H}=-\Sigma \mathrm{P}_{\mathrm{i}} \ln \mathrm{P}_{\mathrm{i}}$ (Shannon and Weaver, 1949)

Margalef's richness index, $\mathrm{D}=(\mathrm{s}-1) /(\ln N)$ (Margalef, 1968)

Pielou's evenness index, $e=\mathrm{H} / \mathrm{InS}$ (Pielou, 1966)

where Relative abundance, $\mathrm{P}_{\mathrm{i}}=\mathrm{s} / \mathrm{N}$

$\mathrm{s}=$ number of individuals of one species

$\mathrm{N}=$ total number of all individuals in the sample

In = natural logarithm. 


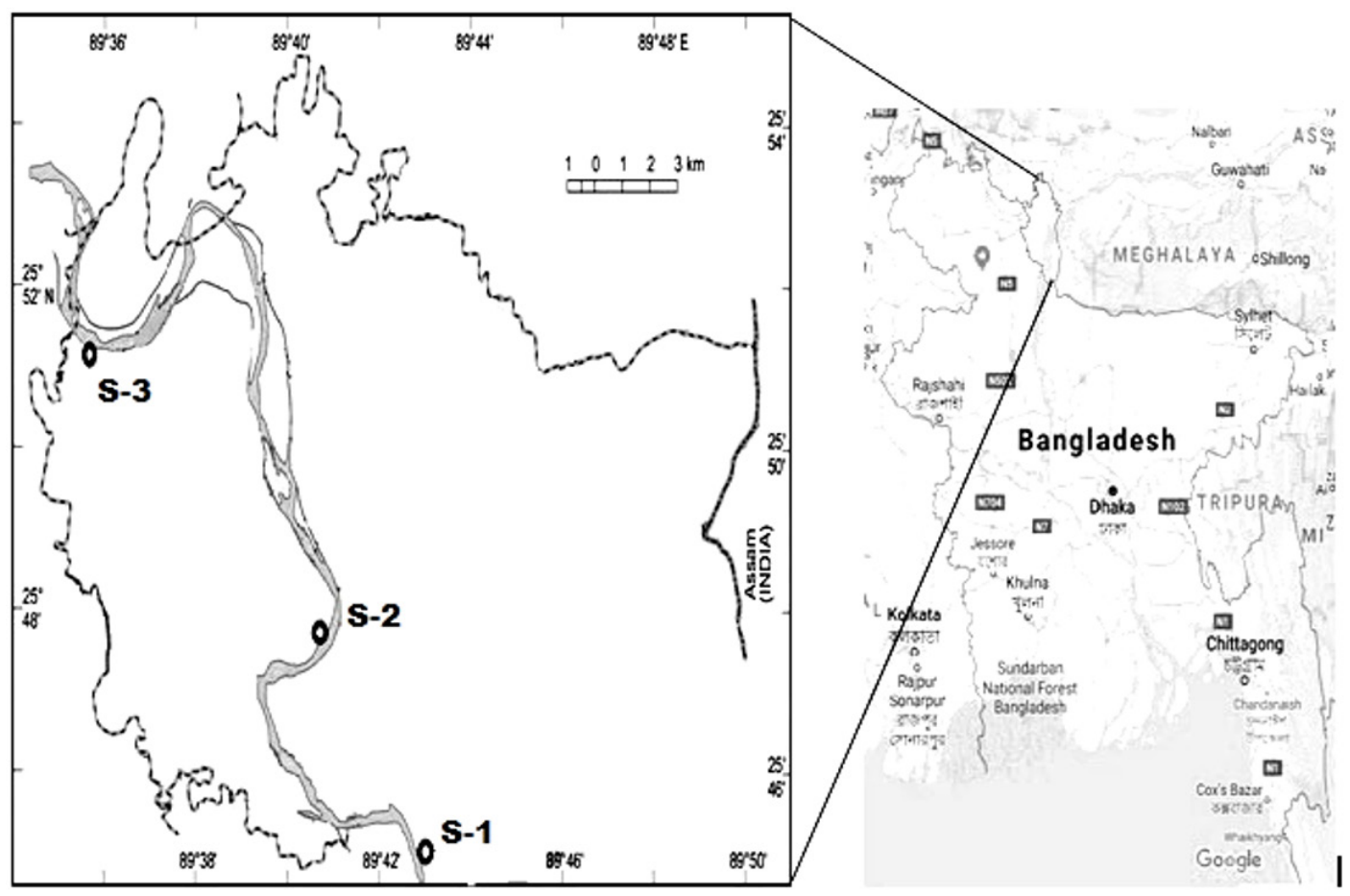

Fig 1. Location of the study area (S-1: Sampling site-1; S-2: Sampling site-2; S-3: Sampling site-3)

\section{RESULTS}

\section{Fish species diversity and IUCN conservation status}

The identified indigenous fish species are listed according to family, scientific name, English name, local name, global and local IUCN status of 2015 in Table 1. Total 76 indigenous fish species belonging to 57 genera, 26 families and 8 orders were recorded during the study period (Table 1). The family with the richest diversity in terms of species number was the Cyprinidae (14 species), followed by the Danionidae (13 species) and Bagridae (8 species). Four species were identified for each of the family Channidae, Siluridae, Sisoridae, Mastacembelidae; and three species for the Ambassidae. Cobitidae, Botiidae, Osphronemidae; Notoperidae had two species each and the rest of the families belonged to a single species (Figure 2).

Besides 76 indigenous fish species, nine exotic fish species were also found in the Dharla River; they were as follows: Ctenopharyngodon idella, Pangasius hypophthalmus, Hypophthalmichthys molitrix, Hypophthalmichthys nobilis, Barbonymus gonionotus, Clarias gariepinus, Oreochromis mossambicus, Anabas testudineus (thai koi), Cyprinus Carpio.

Among the identified fishes, 28 species (37\%) were considered as threatened under the categories of critically endangered $(5 \%)$, endangered $(20 \%)$ and vulnerable (12\%), according to the Red List of IUCN (2015) (Figure 3). Of the 28 indigenous threatened species in the Dharla River, 13 species belonged to the order Cypriniformes, followed by 10 species of Siluriformes, two (02) species of Synbranchiformes and only one (01) species of
Perciformes. In the present study, two species were identified in the order Osteoglossiformes and both species were detected as threatened (Figure 4).

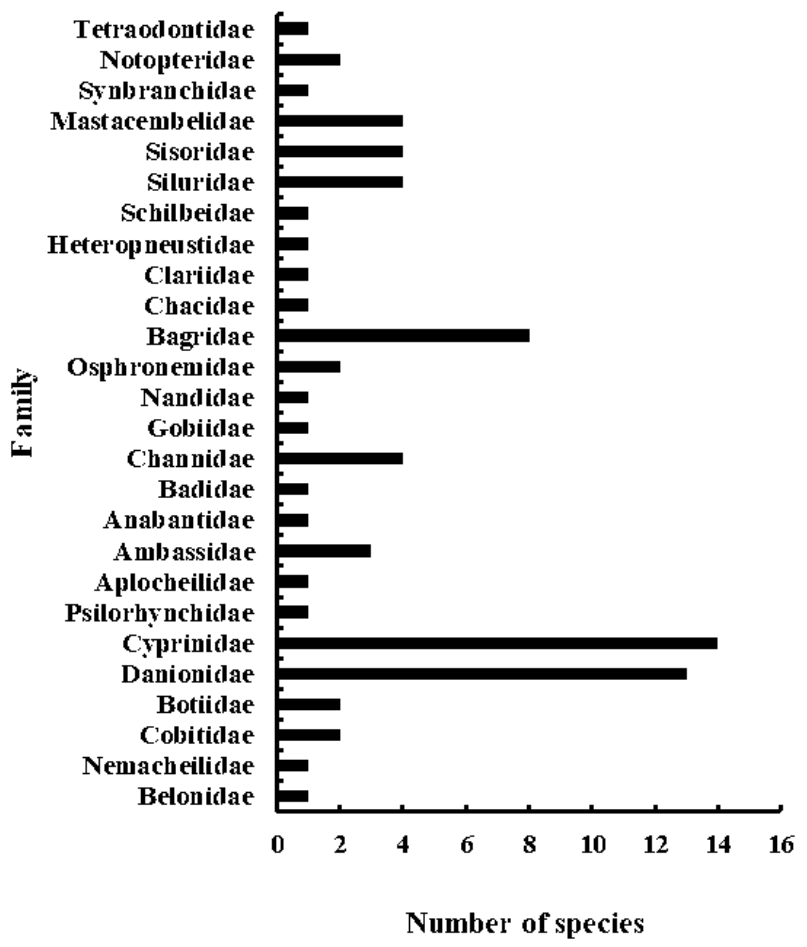

Fig 2. Number of fish species within different families collected from January to December 2018 at the Dharla River 
Table 1. List of indigenous fish species found from January to December 2018 in the Dharla River (IUCN status: CR $=$ Critically Endangered, $\mathrm{EN}=$ Endangered, $\mathrm{VU}=$ Vulnerable, NT $=$ Near Threatened, $\mathrm{LC}=$ Least Concern, $\mathrm{DD}=$ Data Deficient, NE $=$ Not Evaluated)

\begin{tabular}{llll}
\hline \hline Order and Family Scientific name & English name & Local name & $\begin{array}{l}\text { Local Status } \\
\text { Global status } \\
\text { (IUCN 2015) }\end{array}$ \\
\hline ORDER: BELONIFORMES 2015)
\end{tabular}

\section{ORDER: BELONIFORMES}

Belonidae

Xenentodon cancila (Hamilton 1822)

Freshwater garfish

Kankila

LC

NE

\section{ORDER: CYPRINIFORMES}

Nemacheilidae

Cobitidae

Botiidae

Danionidae

(1)

Cyprinidae

Garra gotyla (Gray 1830)
Chagunius chagunio (Hamilton 1822)
Cirrhinus reba (Hamilton 1822)
Labeo gonius (Hamilton 1822)
Tariqilabeo latius (Hamilton 1822)
Labeo bata (Hamilton 1822)
Labeo boga (Hamilton 1822)
Labeo calbasu (Hamilton 1822)
Labeo rohita (Hamilton 1822)
Osteobrama cotio (Hamilton 1822)
Puntius sophore (Hamilton 1822)
Pethia ticto (Hamilton 1822)
Systomus sarana (Hamilton 1822)
Psilorhynchus balitora (Hamilton 1822)

Paracanthocobitis botia (Hamilton 1822)

Canthophrys gongota (Hamilton 1822)

Botia lohachata Chaudhuri 1912

Botia Dario (Hamilton 1822)

Cabdio jaya (Hamilton 1822)

C. morar (Hamilton 1822)

Barilius barila (Hamilton 1822)

Opsarius barna (Hamilton 1822)

Barilius shacra (Hamilton 1822)

Bengala elanga (Hamilton 1822)

Chela cachius (Hamilton 1822)

Devario devario (Hamilton 1822)

Esomus danrica (Hamilton 1822)

Raiamas bola (Hamilton 1822)

Rasbora daniconius (Hamilton 1822)

S. phulo (Hamilton 1822)

Gibelion catla (Hamilton 1822)

Garra gotyla (Gray 1830)

Chagunius chagunio (Hamilton 1822) Lepidocephalichthys guntea (Hamilton 1822)

Amblypharyngodon mola (Hamilton 1822)

\section{Chaguni}

Reba carp

Kuria labeo

Hill stream carp

Bata labeo

Boga labeo

Black rohu

Rohu carp

Cotio

Pool barb

Ticto barb

Olive barb

Balitora minnow
Balichata

Puiya

Pahari gutum

Rani

Rani

Jaya

Morari

Mola

Barali

Bani koksa

Koksa

Along

Chep chela

Chapchela

Darkina

Bhol

Darkina

Ful Chela

Katal

Ghorpoia

Jarua

Korki

Ghannya

Kala bata

Bata

Bhangan

Kalibaus

Rui

Dhela

Jatpunti

Tit punti

Sarpunti

Balitora
LC

LC

NT

EN

EN

LC

vU

$$
\text { LC }
$$

DD

EN

$$
\text { LC }
$$

EN

vu

LC

DD

EN

LC

LC

LC

EN

VU

NT

NT

EN

LC

LC

LC

LC

NE

LC

NE

NE

LC

LC

LC

LC

LC

LC

LC

NE

LC

LC

NT

NE

LC

LC

LC

LC

LC

LC

LC

CR

LC

LC

LC

LC

LC

LC

LC

LC

LC 
Continued.

\begin{tabular}{|c|c|c|c|c|c|}
\hline Order and Family & Scientific name & English name & Local name & $\begin{array}{l}\text { Local Status } \\
\text { (IUCN 2015) }\end{array}$ & $\begin{array}{l}\text { Global st } \\
\text { (IUCN } 2\end{array}$ \\
\hline \multicolumn{6}{|c|}{ ORDER: CYPRINODONTIFORMES } \\
\hline Aplocheilidae & Aplocheilus panchax (Hamilton 1822) & Panchax minnow & Kanpona & LC & \\
\hline \multicolumn{6}{|c|}{ ORDER: PERCIFORMES } \\
\hline \multirow[t]{3}{*}{ Ambassidae } & Chanda nama (Hamilton 1822) & Elongate glass per-chlet & Chanda & LC & \\
\hline & Pseudambassis ranga (Hamilton 1822) & Indian glossy fish & Rangachanda & LC & \\
\hline & Pseudambassis lala (Hamilton 1822) & Highfin glassy per-chlet & Lalchanda & LC & \\
\hline Anabantidae & Anabas testudineus (Bloch 1792) & Climbing perch & Koi & LC & \\
\hline Badidae & Badis badis (Hamilton 1822) & Badis & Napit Koi & NT & \\
\hline \multirow[t]{4}{*}{ Channidae } & Channa marulius (Hamilton 1822) & Great snake head & Gajar & EN & \\
\hline & Channa punctatus (Bloch 1793) & Spotted snake head & Taki & LC & \\
\hline & Channa striatus (Bloch 1793) & Snake head murrel & Shol & LC & \\
\hline & Channa orientalis Bloch \& Schneider 1801 & Walking snakehead & Cheng & LC & \\
\hline Gobiidae & Glossogobius giuris (Hamilton 1822) & Tank gobi & Baila & LC & \\
\hline Nandidae & Nandus nandus (Hamilton 1822) & Mottled Nandus & Veda & NT & \\
\hline \multirow[t]{2}{*}{ Osphronemidae } & Trichogaster fasciata Bloch \& Schneider 1801 & Banded gourami & Kholisha & LC & \\
\hline & Trichogaster lalius (Hamilton 1822) & Dwarf gourami & Lalkhailsha & LC & 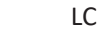 \\
\hline
\end{tabular}

ORDER: SILURIFORMES

\begin{tabular}{|c|c|c|c|c|}
\hline Bagridae & Batasio tengana (Hamilton 1822) & Dwarf catfish & Tengra & EN \\
\hline & Hemibagrus menoda (Hamilton 1822) & Menoda catfish & Gang tengra & NT \\
\hline & Mystus bleekeri (Day 1877) & Day's mystus & Gulshatengra & LC \\
\hline & Mystus cavasius (Hamilton 1822) & Gangetic mystus & Kabashi tengra & NT \\
\hline & Mystus tengara (Hamilton 1822) & Stripped dwarf catfish & Bujritengra & NT \\
\hline & Mystus vittatus (Bloch 1794) & Stripped river catfish & Tengra & NT \\
\hline & Rita rita (Hamilton 1822) & Rita & Rita & EN \\
\hline & Sperata aor (Hamilton 1822) & Long-whiskered catfish & Ayre & VU \\
\hline Chacidae & Chaca chaca (Hamilton 1822) & Squarehead catfish & Chaka & EN \\
\hline Clariidae & Clarias batrachus (Hamilton 1822) & Walking catfish & Magur & LC \\
\hline Heteropneustidae & Heteropneustes fossilis (Bloch 1794) & Stinging catfish & Shing & LC \\
\hline Schilbeidae & Ailia coila (Hamilton 1822) & Gangetic ailia & Baspata & LC \\
\hline Siluridae & Clupisoma garua (Hamilton 1822) & Vacha & Bacha & EN \\
\hline & Ompok pabda (Hamilton 1822) & Two stripe pabda catfish & Madhupabda & EN \\
\hline & O. pabo (Hamilton 1822) & Pabo catfish & Kala pabda & CR \\
\hline & Wallago attu (Hamilton 1822) & Freshwater shark & Boal & VU \\
\hline Sisoridae & Bagarius bagarius (Hamilton 1822) & Devil catfish & Baghair & CR \\
\hline & Gagata gagata (Hamilton 1822) & Gangetic gagata & Gang tengra & LC \\
\hline & Sisor rabdophorus (Hamilton 1822) & Sisor catfish & Sai sore & CR \\
\hline & Conta conta (Hamilton 1822) & Conta catfish & Hara machh & NT \\
\hline
\end{tabular}


Continued.

\begin{tabular}{|c|c|c|c|c|c|}
\hline Order and Family & Scientific name & English name & Local name & $\begin{array}{l}\text { Local Status } \\
\text { (IUCN 2015) }\end{array}$ & $\begin{array}{l}\text { Global status } \\
\text { (IUCN 2015) }\end{array}$ \\
\hline \multicolumn{6}{|c|}{ ORDER: SYNBRANCHIFORMES } \\
\hline \multirow[t]{4}{*}{ Mastacembelidae } & Macrognathus aral (Bloch \& Schneider 1801) & One-stripe Spiny Eel & Tara baim & DD & LC \\
\hline & M. pancalus (Hamilton 1822) & Stripped spiny eel & Guchibaim & LC & LC \\
\hline & M. aculeatus (Bloch 1786) & Spotted spiny eel & Tara baim & NT & NE \\
\hline & Mastacembelus armatus (Lacepede 1800) & Tire track spiny eel & Sal baim & EN & NE \\
\hline Synbranchidae & Monopterus cuchia (Hamilton 1822) & Freshwater mud eel & Kuchia & VU & VU \\
\hline \multicolumn{6}{|c|}{ ORDER: OSTEOGLOSSIFORMES } \\
\hline \multirow[t]{2}{*}{ Notopteridae } & Chitala chitala (Hamilton 1822) & Clown knife fish & Chital & EN & NT \\
\hline & Notopterus notopterus (Pallas 1769) & Bronge feather back & Foli & VU & LC \\
\hline \multicolumn{6}{|c|}{ ORDER: TETRAODONTIFORMES } \\
\hline Tetraodontidae & Leiodona cutcutia (Hamilton 1822) & Ocellated puffer fish & Tepa & LC & LC \\
\hline
\end{tabular}

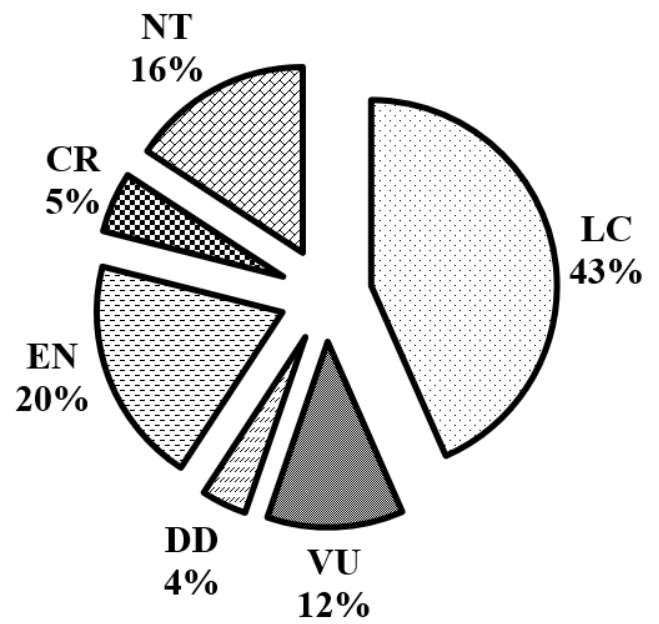

Fig 3. Threatened status of identified fishes at the Dharla River in Bangladesh collected from January to December 2018 (CR- Critically Endangered, EN- Endangered, VUVulnerable, NT- Near Threatened, LC- Least Concern, DDData Deficient)

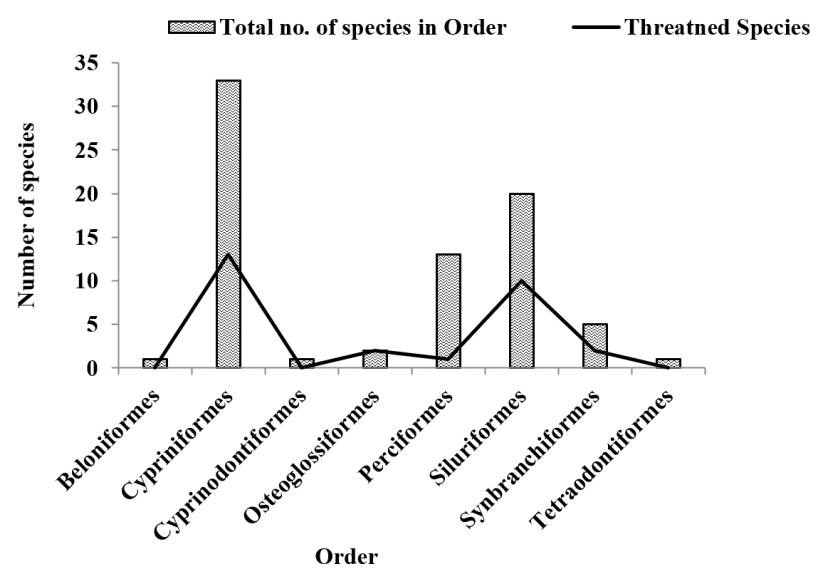

Fig 4. Order-wise threatened fish species diversity in the Dharla River

\section{Diversity, richness and evenness indices}

The values of different diversity indices are represented in Table 2. The Shannon-Weaver diversity $(H)$, Pielou's evenness $(e)$ and Margalef's richness $(D)$ index of the Dharla River during the study period ranged from 3.00 (July) to 3.71 (January), 0.62 (September) to 0.94 (June) and 3.94 (July) to 7.95 (January), respectively. The higher value of Shannon-Weaver diversity and Margalef's richness indices were found between October and February, whereas Pielou's evenness was higher between May and August (Table 2).

\section{DISCUSSION}

Freshwater biodiversity of inland waters constitutes a valuable natural resource (Hiddink et al., 2008). Fish biodiversity of inland open waters is highly diversified (Hussain, 2010). Biodiversity and its conservation are regarded as a major issue for biologists towards sustainable use (Kar et al., 2006). The Dharla River is no exception.

The Dharla River is located in the northern part of Bangladesh and a total of 76 indigenous fish species were recorded from this river by the present study. In northern Bangladesh, Bhuiyan et al. (2008) identified 73 fish species in the Padma River near Rajshahi, and Parvez et al. (2014) identified 84 species from three major rivers, i.e. the Dhepa, the Punarbahaba and the Atrai, in the Dinajpur district. However, the scenario was opposite to the previous record. For example, Islam and Hossain (1983) and Hossain and Haque (2005) recorded 110 and 134 species of fish, respectively, from the Padma River. The number of fish species was higher than in the present study. The lower number of fish species of the present study compared to the previous assessment is evidence of the gradual loss of biodiversity in the study area. 
Table 2. Total number of species and total number of individuals recorded with Shannon-Weaver diversity $(H)$, Pielous evenness $(e)$ and Margalef richness $(D)$ values during the study period

\begin{tabular}{|c|c|c|c|c|c|}
\hline Month & Number of species & $\begin{array}{c}\text { Total number of } \\
\text { Individuals }\end{array}$ & $\begin{array}{c}\text { Shannon-Weaver } \\
\text { Diversity }(H)\end{array}$ & Pielous Even-ness $(e)$ & Margalef Richness (D) \\
\hline January & 54 & 788 & 3.71 & 0.75 & 7.95 \\
\hline February & 52 & 743 & 3.66 & 0.75 & 7.72 \\
\hline March & 47 & 541 & 3.64 & 0.81 & 7.31 \\
\hline April & 26 & 250 & 3.11 & 0.86 & 4.53 \\
\hline May & 22 & 232 & 3.08 & 0.91 & 4.39 \\
\hline June & 22 & 196 & 3.03 & 0.94 & 3.98 \\
\hline July & 22 & 206 & 3.00 & 0.92 & 3.94 \\
\hline August & 27 & 200 & 3.20 & 0.91 & 4.91 \\
\hline September & 37 & 342 & 3.13 & 0.62 & 6.17 \\
\hline October & 37 & 405 & 3.49 & 0.89 & 6.00 \\
\hline November & 38 & 616 & 3.51 & 0.88 & 5.76 \\
\hline December & 35 & 608 & 3.48 & 0.93 & 5.30 \\
\hline
\end{tabular}

Resembling the present study, the Cypriniformes was illustrated as the most dominant fish order in the Padma River of northwestern Bangladesh by Rahman et al. (2012). This finding was also similar to the previous study by Parvez et al. (2019) from three rivers, i.e. the Dhepa, the Punarbahaba and the Atrai, in the Dinajpur district in Bangladesh. This finding is also consistent with the study of Parvez et al. (2017) in the Dhepa River fish sanctuary. Hasan et al. (2013) also found the Cyprinidae as the dominant fish family in Baikka beel followed by the family Bagridae, Siluridae and Channidae.

In the current study, there were nine (9) reported exotic fish in the Dharla River, which was quite higher than that of Alam et al. (2013) who found three exotic fish species in the Halda River. Galib et al. (2013) recorded two exotic species in the Choto Jamuna River, Saha and Hossain (2002) found six exotic species in Saldu beel, Parvez et al. (2017) identified seven (7) exotic fishes from the Dhepa River fish sanctuary. However, the present findings of this study are consistent with those of Parvez et al. (2014) who recorded 12 exotic species in three rivers of the Dinajpur district. The recorded species were very popular in the aquaculture of Bangladesh and also in the Kurigram district from where the fish samples were collected. Due to heavy floods in 2017 in the study area, these species escaped from the aquaculture ponds. These alien species can create a threat to our indigenous species (Mijkherjee et al., 2002). Parallel observations were also made by different researchers (Rixon et al., 2005). To overcome such potential impact on native biodiversity, no alien fish species should be introduced without studying the details of life history and potential impact on the natural ecosystem, with a strong monitoring system. Besides, no predatory exotic fish species should be introduced in the indigenous ecosystem and people should be motivated to cultivate alternative indigenous fish species. The authorities should develop national guidelines and protocols for introducing alien species in the endemic ecosystem with proper legislative control (Hossain et al., 2018).

IUCN (2015) recognized an increase of $18.5 \%$ of threatened fish between 2000 to 2015 in Bangladesh due to different anthropological causes. IUCN (2015) also identified 64 threatened species (25.3\%) in Bangladesh, which is quite different to the present $(37 \%)$ study. Due to assessing a large number of species (253) by IUCN, the percentages of threatened species was probably reduced. Besides, Galib et al. (2013) identified a large number of fish species (41.72\%) as threatened from the River Choto Jamuna of the northern part of Bangladesh. In addition, $32.8 \%$ of threatened fish species were identified in the northwestern part of Bangladesh from the study by Parvez et al. (2019).

It is interesting to note that 28 threatened species were found in the Dharla River, which is very similar to the studies of Galib et al. (2009) in Chalan Beel, Mohsin et al. (2013) in the Padma River, Imteazzaman and Galib (2013) in Halti Beel, and Galib (2015) in the Brahmaputra River, Bangladesh who found 28, 26, 22 and 24 threatened indigenous species, respectively. Yet Mohsin et al. (2014) reported a small number of threatened fishes (10) from the Andharmanik River of southern Bangladesh, which 
is quite different to this study. The threatened ranks of indigenous species were Endangered (20\%), Vulnerable (12\%) and Critically Endangered (5\%). These findings are broadly supported by Parvez et al. (2017) and Galib (2015).

The maximum number of fish species and the total number of individuals were found between September and March. It seems that water level became lower compared to other months which allowed fishermen to operate fishing gear more effectively and resulting in increased catch from the Dharla River. Likewise, lower levels of water form difficulty in niche segregation and fishes facing intra- and interspecific competition, so fishes become more susceptible to catch by fishermen (Shaikh et al., 2011). A similar observation was found by Galib et al. (2013) in the Choto Jamuna River of the northwest region in Bangladesh. Nath and Deka (2012) also observed the richest fish diversity in the winter months.

The Shannon-Weaver diversity index $(H)$ ranges typically from 1.5 to 3.5 and rarely reaches 4.5 . A high value of $H$ represents a diverse and equally distributed community, whereas lower values represent a less diverse community (Gaines, 1999). The range of Margalef's richness index has no limit and shows a perfect linear relationship with species richness (Gamito, 2010). Pielou's evenness $(e)$ is the count of individuals of each species in an area and ranges from zero to one, zero signifying no evenness and one, a complete evenness (Pielou, 1966). The lower value of the Shannon-Weaver diversity index $(H)$ was observed in the months from April to August as the water level was higher, which makes fishing very difficult (Galib et al. 2013). The lower values of the Shannon-Weaver diversity index in the monsoon months also indicate environmental stress (Acharjee and Barat, 2014). The Shannon-Weaver diversity $(H)$ values (3.49-3.66) and Margalef's richness $(D)$ values (6.00-7.72) were higher in winter months but evenness values were lower (0.89-0.75), which indicates fish species were not evenly distributed in the water column. This is because niche segregation was hampered due to the absence of deep water levels (Samal et al., 2014). The values of diversity and richness indices in this study were found to be greater than that of Yisa et al. (2011), Innocent et al. (2012) and Galib et al. (2013), indicating comparatively richer biodiversity in the study area of the Dharla River. In the current century, riverine ecosystems faced alarming threats due to the loss of fish diversity through different anthropological and natural causes (IUCN, 2015). To maintain the ecological and socioeconomic equilibrium, conservation of fish diversity is very essential (Lakra, 2010).

The Dharla River is rich in indigenous fish biodiversity and serves as a harbor for threatened fishes. In this river, fishermen use destructive fishing gears like current jal (small meshed monofilament net, mesh size 0.5-1.27 cm), small mesh ber jal (seine net, mesh size 0.5-1.0 cm) for catching juvenile fish and poison fishing, especially in the winter season (authors' personal observation). To conserve sustainable biodiversity, it is urgently needed to eliminate all destructive fishing and formulate an action plan for sustainable biodiversity conservation. Major portion of fish species in the Dharla River has been identified as threatened species in the present study, which strongly supports its potentiality for the establishment of a natural conservation site. The establishment of a seasonal and permanent fish sanctuary could serve as a gene pool of the threatened fishes in the Dharla River. The findings of this research provide insights into the necessity of conservation of the indigenous fish diversity. Therefore it is very essential to periodically update the checklist of fish diversity of specific water bodies to retrieve the information, knowledge and changing scenarios. Besides, there is a burning need to develop a strong monitoring protocol in order to evaluate the progress of reducing losses of biodiversity, uproot the causes of biodiversity losses and assess the changes of track of threatened fish populations.

\section{ACKNOWLEDGMENTS}

The authors acknowledge the Rural Development Academy (RDA), Bogura, Bangladesh for financial support to this research. We are also thankful to local administration, local fishermen and fish traders for their boundless help during the collection of data. The authors are grateful to Sadhan Verma for his inputs for editing the image of the map and Md. Tanbirul Islam for his valuable comments during the preparation of the manuscript.

\section{RAZNOLIKOST I STUPANJ UGROŽENOSTI RIBA RIJEKE DHARLA U BANGLADEŠU}

\section{SAŽETAK}

Raznolikost riba riječnog ekosustava postala je smanjena zbog različitih nepogoda uzrokovanih čovjekom i prirodom. U ovoj studiji, u razdoblju od siječnja do prosinca 2018. godine istraživan je trenutni status biološke raznolikosti riba u rijeci Dharla koja se nalazi $\left(25,8103^{\circ} \mathrm{S}, 89,6487^{\circ} \mathrm{E}\right)$ u sjevernom dijelu Bangladeša. U ovoj je studiji postojeći status biološke raznolikosti riba u rijeci Dharla procijenjen prema indeksu raznolikosti i statusa ugroženosti (kako globalnog, tako i lokalnog). Podaci za uzimanje uzoraka prikupljeni su s tri mjesta na rijeci pomoću različitih ribolovnih alata $i$ tri odabrane ribarnice smještene $u$ okrugu Kurigram u Bangladešu. Ukupno je identificirano 76 vrsta riba koje pripadaju u 8 redova, 26 porodica i 57 rodova. Porodica Cyprinidae koja je bila najdominantnija, bila je zastupljena s 14 vrsta, zatim Danionidae (13 vrsta), Bagridae (8 vrsta) i nekoliko manjih porodica. Osim autohtonih vrsta, zabilježeno je i devet egzotičnih vrsta riba. Indeksi raznolikosti prema Shannon-Weaveru (H), ujednačenosti Pielous (e) i bogatstva Margalefa (D) kretali 
su se od 3,00 do $3,71,0,62$ do 0,94 i 3,94 do 7,95 . Od 76 autohtonih vrsta, 28 vrsta (37\%) identificirano je kao ugroženo u Bangladešu, što uključuje kritično ugrožene (4 vrste), ranjive (9 vrsta) i ugrožene (15 vrsta). Neselektivni ribolov trovanjem i razornim ribolovnim spravama identificirani su kao glavne prijetnje biološkoj raznolikosti riba na rijeci Dharla. lako rijeka Dharla služi kao značajna potpora ugroženim autohtonim ribama, potrebni su određeni koraci da se zaustavi razarajući ribolov, uspostave trajna utočišta za ribe i odgovarajući nadzor za održavanje održive biološke raznolikosti.

Ključne riječi: Autohtone ribe, IUCN, Indeks biološke raznolikosti, Očuvanje

\section{REFERENCES}

Acharjee, M. L., Barat, S. (2014): Seasonal dynamics of ichthyodiversity in a hill stream of the Darjeeling Himalaya, West Bengal, India. Journal of Threatened Taxa, 6, 14, 66356648.

Alam, M. S., Hossain, M. S., Monwar, M. M., Hoque, M. E., Taimur, F. M. (2013): Check-list of bony fish collected from the Upper Halda River, Chittagong, Bangladesh. Aquaculture, Aquarium, Conservation \& Legislation, 6, 4, 333-338.

BBS (Bangladesh Bureau of Statistics). (2018): Statistical yearbook of Bangladesh. Bangladesh Bureau of Statistics, statistics division, Ministry of Planning, Government of Peoples Republic of Bangladesh, Dhaka. $45 \mathrm{pp}$.

Bhuiyan, S. S., Joadder, M. A. R., Bhuiyan, A. S. (2008): Occurrence of fishes and non-fin fishes of the River Padma near Rajshahi, Bangladesh. University Journal of Zoology, Rajshahi University, 27, 99-100.

Chakraborty, B. K., Nur, N. N. (2009): Study on aquatic biodiversity of Medha beel in the Northern region of Bangladesh. Journal of Crop and Weed, 5, 2, 4-11.

Chowdhury, M. H. (2012): Dharla River. In. Banglapedia: National Encyclopedia of Bangladesh (Second edition). Asiatic Society of Bangladesh. [cited 2015 January 20]. Available from: http://en.banglapedia.org/index.php?title=Dharla_River.

DoF (Department of Fisheries). (2019): National Fish Week 2019 Compendium (In Bang/a). Department of Fisheries, Ministry of Fisheries \& Livestock, Dhaka, Bangladesh. 160 pp.

Eschmeyer, W. N. (2014): Catalog of Fishes electronic version. http://research.calacademy.org/ ichthyology/catalog/fishcat main.asp.

Gaines, W. L. (1999): Monitoring biodiversity: quantification and interpretation (Vol. 443). US Department of Agriculture, Forest Service, Pacific Northwest Research Station.

Galib, S. M. (2015): Fish fauna of the Brahmaputra River, Bangladesh: richness, threats and conservation needs. Journal of fisheries, 3, 3, 285-292.

Galib, S. M., Naser, S. A., Mohsin, A. B. M., Chaki, N., Fahad, M. F. H. (2013): Fish diversity of the River Choto Jamuna, Bangladesh: present status and conservation needs. International journal of biodiversity and conservation, 5, 6, 389-395.

Galib, S. M., Samad, M. A., Mohsin, A. B. M., Flowra, F. A., Alam, M. T. (2009): Present status of fishes in the Chalan Beel-the largest beel (wetland) of Bangladesh. International Journal of Animal and Fisheries Science, 2, 3, 214-218.

Gamito, S. (2010): Caution is needed when applying Margalef diversity index. Ecological Indicators, 10, 2, 550-551.
Gökçe, D. (2019). Introductory Chapter: Current Status of Freshwater Ecosystems. In Limnology-Some New Aspects of Inland Water Ecology. IntechOpen. 4-10 pp.

Hanif, M. A., Siddik, M. A. B., Chaklader, M. R., Nahar, A., Mahmud, S. (2015): Fish diversity in the southern coastal waters of Bangladesh: present status, threats and conservation perspectives. Croatian Journal of Fisheries: Ribarstvo, 73, 4, 148-161.

Hasan, S. J., Flura, A. A., Alam, A. S., Haider, I., Karim, E. (2013): Ecological Aspects and Affectivity of Biodiversity Restoration of Baikka Beel, Moulovibazar. International Journal of Business, Social and Scientific Research, 01, 09-16.

Hiddink, J. G., MacKenzie, B. R., Rijnsdorp, A., Dulvy, N. K., Nielsen, E. E., Bekkevold, D., Heino, M., Lorance, P., Ojaveer, H. (2008): Importance of fish biodiversity for the management of fisheries and ecosystems. Fisheries Research, 90, 1-3, 6-8.

Hossain, M. A., Haque, M. A. (2005): Fish species composition in the river Padma near Rajshahi. Journal of Life and Earth Science, 1, 1, 35-42.

Hossain, M.Y., Vadas, R.L., Ruiz-Carus, R., Galib, S.M. (2018): Amazon sailfin catfish Pterygoplichthys pardalis (Loricariidae) in Bangladesh: a critical review of its invasive threat to native and endemic aquatic species. Fishes, 3, 1, 1-12.

Hussain, M. G. (2010): Freshwater fishes of Bangladesh: Fisheries, biodiversity and habitat. Aquatic Ecosystem Health \& Management, 13, 1, 85-93.

Imteazzaman, A. M., Galib, S. M. (2013): Fish fauna of halti beel, Bangladesh. International Journal of Current Research, 5, 1, 187-190.

Innocent, B. X., Karuthapandi, M., Fathima, M. S. A. (2012): Fish Faunal Diversity of Suthamalli Pond, Tirunelveli District, Tamilnadu. International Journal of Advance Life Science, 1, 73-79.

Islam, M. S., Hossain, M. A. (1983): An account of the fisheries of the Padma near Rajshahi. Rajshahi Fisheries Bulletin, 1, 2, 1-3.

IUCN (International Union for Conservation of Nature). (2015): Red List of Bangladesh Volume 5: Freshwater Fishes. IUCN, Bangladesh Country Office, Dhaka, Bangladesh, 360 pp.

Kar, D., Nagarathna, A. V., Ramachandra, T. V., Dey, S. C. (2006): Fish diversity and conservation aspects in an aquatic ecosystem in Northeastern India. Zoos' Print Journal, 21, 7, 2308-2315.

Lakra, W. S. (2010): Fish biodiversity of Uttar Pradesh: issues of livelihood security, threats and conservation. In National Conference on Biodiversity, Development and Poverty Alleviation. Uttar Pradesh State Biodiversity Board, India, 40$45 \mathrm{pp}$.

Margalef, R. (1968): Perspectives in Ecological Theory. Chicago: University of Chicago Press.

Mijkherjee, M., Praharaj, A., Das, S. (2002): Conservation of endangered fish stocks through artificial propagation and larval rearing technique in West Bengal, India. Aquaculture Asia, 7, 2, 8-11.

Mohsin, A. B. M., Haque, S. M. M., Galib, S. M., Fahad, M. F. H., Chaki, N., Islam, M. N., Rahman, M. M. (2013): Seasonal abundance of fin fishes in the Padma River at Rajshahi district, Bangladesh. World Journal of Fish and Marine Sciences, 5, 6, 680-685.

Mohsin, A. B. M., Yeasmin, F., Galib, S. M., Alam, B., Haque, S. M. M. (2014): Fish fauna of the Andharmanik River in Patuakhali, Bangladesh. Middle-East Journal of Scientific Research, 21, 5, 802-807. 
Nath, B., Deka, C. (2012): A study on fish diversity, conservation status and anthropogenic stress of Chandubi tectonic lake, Assam, India. Journal of Bio Innovation, 1, 6, 148-155.

Parvez, I., Alam, M. A., Hassan, M. M., Ara, Y., Hoshan, I., Kibria, A. S. M. (2019): A checklist of fish species from three rivers in northwestern Bangladesh based on a seven-year survey. Journal of Threatened Taxa, 11, 6, 13786-13794.

Parvez, I., Mostakim, G. M., Ali, M. R., Sujan, H. S., Alam, M. A. (2014): Present Status and Potential Risks of Fishes of Northwest Bangladesh (2014 December 22). The Festschrift on the 50th Anniversary of The IUCN Red List of Threatened Species, $102 \mathrm{pp}$.

Parvez, I., Sujan, H. S., Alam, M. A., Akter, M. N., Roy, K., Haque, M. R. (2017): Fish biodiversity and conservation status of the Dhepa River Sanctuary in protection and restoration of threatened fishes of the northwest Bangladesh. Journal of Biodiversity and Environmental Sciences, 10, 1, 183-190.

Pielou, E. C. (1966): Species diversity and pattern diversity in the study of ecological succession. Journal of Theoretical Biology 13, 131-144.

Rahman, A. K. A. (2005): Freshwater Fishes of Bangladesh (Second edition). Zoological Society of Bangladesh, University of Dhaka, Dhaka, Bangladesh. 394pp.

Rahman, M. M., Hossain, M. Y., Ahamed, F., Fatematuzzhura, S. B., Abdallah, E. M., Ohtomi, J. (2012): Biodiversity in the Padma distributary of the Ganges River, northwestern Bangladesh: recommendations for conservation. World Journal of zoology, 7, 4, 328-337.

Rao, J. C. S., Raju, C. S., Simhachalam, G. (2014): Biodiversity and Conservation Status of Fishes of River Sarada, Visakhapatnam District, Andhra Pradesh, India. Research Journal of Animal, Veterinary and Fishery Sciences, 2, 2, 1-8.

Rixon, C. A., Duggan, I. C., Bergeron, N. M., Ricciardi, A., Macisaac, H. J. (2005): Invasion risks posed by the aquarium trade and live fish markets on the Laurentian Great Lakes. Biodiversity \& Conservation, 14, 6, 1365-1381.
Samal, N. R., Roy, P. K., Majumadar, M., Bhattacharya, S., Biswasroy, M. (2014): Six Years Major Historical Urban Floods in West Bengal State in India: Comparative Analysis Using Neuro-Genetic Model. American Journal of Water Resources, 2, 2, 41-53.

Shaikh, H. M., Kamble, S. M., Renge, A. B. (2011): The study of ichthyofauna diversity in upper Dudhna project water reservoir near Somthana in Jalna district (MS) India. Journal of Fisheries and Aquaculture, 2, 1, 8-10.

Shannon, C. E., Weaver, W. (1949): The Mathematical Theory of Communication. Urbana, IL: University of Illinois Press.

Sharker, M. R., Siddik, M. A. B., Nahar, A., Shahjahan, M., Faroque, A. (2015): Genetic differentiation of wild and hatchery populations of Indian major carp Cirrhinus cirrhosus in Bangladesh. Journal of Environmental Biology, 36, 5, 12231227.

Siddik, M. A. B., Nahar, A., Ahsan, M., Ahamed, F., Hossain, M. (2014): Over-wintering growth performance of mixedsex and mono-sex Nile tilapia Oreochromis niloticus in the Northeastern Bangladesh. Croatian Journal of Fisheries, 72, 2, 70-76.

Siddique, M. A. B., Hussain, M. A., Flowra, F. A., Alam, M. M. (2016): Assessment of fish fauna in relation to biodiversity indices of Chalan Beel, Bangladesh. International Journal of Aquatic Biology, 4, 5, 345-352.

Talwar, P. K., Jingran, A. G. (1991): Inland Fishes of India and Adjacent Countries. Oxford and IBH Publishing Company, New Delhi. 936-1023 pp.

Yisa, T. A., Adeyemi, R. A., Ibrahim, I. (2011): Evaluation of Diversity Index of Fish Fauna in a Lowland Rice Field in Southern Guinea Savannah of Northern Nigeria. International Journal of Science and Nature, 2, 4, 809-812. 